Article

\title{
The Opposite of Biotic Resistance: Herbivory and Competition Suppress Regeneration of Native but Not Introduced Mangroves in Southern China
}

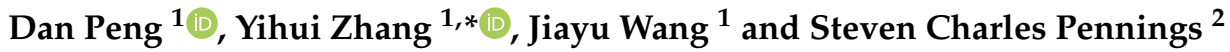 \\ 1 Key Laboratory of the Ministry of Education for Coastal and Wetland Ecosystems, College of the \\ Environment and Ecology, Xiamen University, Xiamen 361102, China; pengdann@outlook.com (D.P.); \\ wangjy147@foxmail.com (J.W.) \\ 2 Department of Biology and Biochemistry, University of Houston, Houston, TX 77204, USA; \\ scpennin@Central.UH.EDU \\ * Correspondence: zyh@xmu.edu.cn
}

check for

updates

Citation: Peng, D.; Zhang, Y.;

Wang, J.; Pennings, S.C. The Opposite of Biotic Resistance: Herbivory and Competition Suppress Regeneration of Native but Not Introduced Mangroves in Southern China. Forests 2022, 13, 192. https://doi.org/ 10.3390/f13020192

Academic Editors: Martin Zimmer, Véronique Helfer, Jonas C. Geburzi and Daniel Arturo Saavedra Hortua

Received: 16 November 2021

Accepted: 24 January 2022

Published: 26 January 2022

Publisher's Note: MDPI stays neutral with regard to jurisdictional claims in published maps and institutional affiliations.

Copyright: (C) 2022 by the authors. Licensee MDPI, Basel, Switzerland. This article is an open access article distributed under the terms and conditions of the Creative Commons Attribution (CC BY) license (https:// creativecommons.org/licenses/by/ $4.0 /)$.

\begin{abstract}
Mangrove forests are increasingly threatened by plant invasions worldwide, but some mangrove species are invasive and threaten salt marsh and native mangrove ecosystems. The southern coast of China is invaded by the cordgrass Spartina alterniflora, and the mangrove Sonneratia apetala, providing a model system for studying the processes and mechanisms through which non-native species establish and spread. We used a transplant experiment to test the overarching hypothesis that native herbivores and plants provided biotic resistance against invasion by S. apetala, and that the importance of these factors would vary geographically. Survival of transplanted mangrove seedlings was lower in Zhangjiang Estuary $\left(23^{\circ} 55^{\prime} \mathrm{N}\right)$ than in Leizhou Bay $\left(20^{\circ} 56^{\prime} \mathrm{N}\right)$, and varied with species and habitats. S. apetala had higher survival and growth rates than native mangroves at both sites, and S. apetala grew taller than the S. alterniflora canopy at Leizhou Bay in only two growing seasons. In contrast, native mangroves grew poorly in S. alterniflora. Grazing by rodents and insects suppressed the growth and survival of Kandelia obovata and Avicennia marina in Zhangjiang Estuary and Leizhou Bay, but had little effect on S. apetala. Competition with vegetation (S. alterniflora and native mangroves) exacerbated the reduced survival of native mangroves, and these effects varied across study sites. Low survival of non-native S. apetala in vegetated habitats at Zhangjiang Estuary was likely due to a synergistic effect of low winter temperatures and low light intensity. Escape from herbivory (the opposite to biotic resistance) and fast growth may drive the quick expansion of non-native S. apetala in China. Rapid encroachment of $S$. apetala may transform the native mangrove forests and monospecific intertidal Spartina grasslands into non-native mangrove forests in the southern coast of China.
\end{abstract}

Keywords: biological invasion; biotic resistance; mangroves; herbivory; competition; Sonneratia apetala; Spartina alterniflora; Rattus losea

\section{Introduction}

Mangrove forests provide important ecosystem services [1,2], but presently they are severely degraded [3,4]. Human activities such as aquaculture, agriculture, and urban development have caused large-scale mangrove deforestation $[5,6]$. These direct human activities take place in the context of ongoing global changes, such as sea level rise, precipitation, and extreme temperature, that also impact the structure of mangrove communities, their biodiversity, and geomorphological setting [3,7-9]. In contrast to research on human impacts and global change, the role of plant invasions in the degradation of mangrove forests has received little attention [10,11].

Biological invasions are a well-known threat to natural ecosystems [12]. A recent literature survey found a total of 57 invasive plants in the world's mangrove forests [10]. 
Plant invasions in mangrove forests could affect sediment nitrogen stocks $[11,13]$ and vegetation structure $[14,15]$, composition, and diversity $[10,16]$. At the same time, mangroves can be invasive species encroaching into other ecosystems. For example, Nypa fruticans invaded native mangrove forests in western Africa, displacing native mangroves and forming dense monospecific stands [17]. In the United States, Rhizophora mangle has invaded Hawaii, where its detritus has a negative effect on faunal communities because of its high tannin content [18]. In the United States, Australasia, and South Africa, mangroves are encroaching into salt marsh habitats, changing microclimates [19,20], vegetation structure, and processes $[8,21,22]$. In comparison to the extensive research on how human activities and global change are affecting mangroves, there has been relatively little attention on the importance of invasions by non-native plants-whether into mangrove forests or by mangroves into other habitats.

The success of an invasive plant is dependent on multiple processes across a wide range of temporal and spatial scales $[23,24]$. A key hypothesis about invasions is the biotic resistance hypothesis, which postulates that resident species are able to hinder the establishment and spread of introduced species through negative biotic interactions such as herbivory and interspecific competition $[25,26]$. When studied, however, the effect of herbivores has been mixed: herbivores can promote [27], deter [28,29], or have no effect on the dominance of non-native plant species [30]. In the case of mangroves, many studies have focused on herbivory on propagules and seedlings of native species [31,32], but few studies have examined the role of herbivory in the invasion of non-native mangroves.

Competition with native species is another factor that could contribute to biotic resistance and limit invasion by non-native species [26]. Interspecific competition for limiting resources such as water, nutrients, and light may affect the establishment of nonnative plants. Many studies have found that competition from native plants has a strong negative effect on non-native plants in grasslands [33], salt marshes [34], and forests [35]. However, although resident competitors can reduce the performance of individual nonnative invaders, competition alone might not be enough to exert strong biotic control against a well-established invader [26]. In the case of mangroves, many studies have focused on competition among native species [36], and between natives and non-natives [14,37], but few studies have examined how herbivory and competition might interact to mediate the invasion by non-native mangroves.

Coastal habitats in China provide a model for studying the processes through which non-native species establish and spread, because intertidal habitats along almost the entire coastline have been heavily affected by two non-native plant species. The cordgrass Spartina alterniflora was deliberately introduced from the United States in 1979 with the goal of protecting the coast from erosion [38]. S. alterniflora has spread by planting and natural dispersal to cover intertidal mudflats along almost the entire Chinese coast [39]. Salt marsh species can be nurse plants to facilitate the survival of mangrove seedlings in harsh conditions [40,41]. Even though S. alterniflora temporarily facilitates the survival of native mangrove seedlings, it mostly competes with seedlings of native mangroves, slowing or preventing mangrove regeneration $[11,14,37]$. The mangrove Sonneratia apetala was introduced to China from Bangladesh in 1985 with the goal of revegetating degraded mangrove forests $[42,43]$. It has spread by planting and natural dispersal to dominate $~ 10 \%$ of the mangrove habitat in China, and now its introduced range encompasses more than 6 degrees of latitude from 19 to $25^{\circ} \mathrm{N}$ [44]. It dominates $\sim 60 \%$ of the mangrove forests that have recently regenerated $[4,45]$. The widespread presence of these two non-native species provides an opportunity to study whether biotic resistance from native communities plays a role in limiting the spread of the non-natives and promoting the persistence of native mangrove forests.

The factors mediating the spread of S. alterniflora in China, and the consequences of this spread for native ecosystems, have been widely reviewed $[29,38,46,47]$. Here, we focus on the spread of $S$. apetala, and how its spread might be affected by native herbivores and competition from native mangroves and the pre-existing invasion of S. alterniflora. One factor 
that might affect the spread of $S$. apetala is herbivory by native consumers. To our knowledge, however, no studies have found that herbivory alone can be sufficient to exclude nonnative mangroves from invading a new habitat. However, herbivory might contribute to biotic resistance in combination with competition and abiotic stress [29,47]. Another factor that might affect the spread of $S$. apetala is competition with native mangroves, or with nonnative S. alterniflora. A number of studies have documented the use of non-native $S$. apetala in mangrove afforestation projects, and its expansion on the Chinese coast $[11,42,43]$. We know less about how $S$. apetala interacts with native mangroves or non-native S. alterniflora, but the limited available evidence suggests that, once it escapes the canopy, S. apetala is competitively dominant over both native mangroves and $S$. alterniflora $[37,43,48]$. The ability of native consumers, native mangroves, and S. alterniflora to resist encroachment by $S$. apetala is likely to vary geographically, because competition intensity and herbivory rates may vary geographically, different mangrove species dominate different portions of the Chinese coastline, S. alterniflora productivity varies geographically [49], and S. apetala is a tropical species that is likely to be limited by cold stress at the high-latitude end of its range $[9,11,43]$. It is unknown how competition with native mangroves and herbivory by native herbivores might combine to provide biotic resistance against the early establishment and expansion of non-native $S$. apetala, and whether these interactions might vary geographically.

We conducted a transplant experiment with native and non-native mangroves at two sites in southern China to test three hypotheses about the abiotic and biotic factors affecting early establishment of two native mangroves, Avicennia marina and Kandelia obovata, and the non-native mangrove $S$. apetala. First, consumer pressure reduces the survival of mangrove seedlings, but affects the non-native species more than the native mangroves. Second, competition reduces mangrove establishment, but again affects the non-native species more than the native mangroves. Third, competition, herbivory, and mortality vary geographically as a function of climate, which native mangrove species is the local dominant, and the productivity of S. alterniflora. Based on our results, we discuss the prognosis for mangrove restoration and conservation in southern China.

\section{Materials and Methods}

\subsection{Study Species}

We studied two native and one non-native mangrove species. K. obovata, a native, is cold tolerant, and has a wide distribution along the southeast coast of China from 17 to $28^{\circ} \mathrm{N}$ [50]. A. marina, also native, is pantropical and has the broadest distribution, both latitudinally and longitudinally, of any mangrove species, extending to New Zealand $\left(38^{\circ} \mathrm{S}\right)$ in the southern hemisphere and to China $\left(26^{\circ} \mathrm{N}\right)$ in the northern hemisphere, with a high tolerance of hypersaline and inundation conditions [2]. S. apetala is native to southern India, Bangladesh, Sri Lanka, and Myanmar $\left(21^{\circ} \mathrm{N}\right.$ ), and grows taller (to $\sim 30 \mathrm{~m}$ ) than either native species [51]. S. apetala was introduced to China from Bangladesh in 1985 and has been widely used in mangrove afforestation efforts since the 1990s because of its fast growth rate and tolerance to environmental stresses [42,45]. It has since become invasive, with effects on coastal geomorphology, hydrology, and plant composition $[10,43]$.

All three mangroves overlap geographically with the salt marsh grass S. alterniflora, which is native to the Atlantic and Gulf Coasts of the United States. It has transformed open mudflats into monospecific, dense vegetation throughout its introduced range along the Chinese coast $\left(19\right.$ to $\left.40^{\circ} \mathrm{N}\right)$, and competes with native marsh plants and mangroves $[14,38,46]$.

Intertidal vegetation in China is consumed by rats and insects. The distribution range of the native rat Rattus losea in southern China $\left(18\right.$ to $\left.30^{\circ} \mathrm{N}\right)$ overlaps broadly with that of mangrove forests. $R$. losea nests on mangrove canopies above the high-tide level, using leaves and branches of mangroves as construction material [52,53]. At sites invaded by S. alterniflora, rats build nests with leaves and stems of $S$. alterniflora, and feed on the ramets of S. alterniflora [29]. The most common leaf-chewing insects that consume mangroves in our study sites are Cryptophlebia ombradelta (Lepidoptera, Tortricidae), which consumes 
K. obovata, Oligochroa cantonella (Lepidoptera, Pyralidae), which consumes A. marina, and Orgyia postica (Lepidoptera, Lymantriidae), which consumes S. apetala [54].

\subsection{Study Sites}

We worked at two study sites (Figure 1), Zhangjiang Estuary near the county of Yunxiao, Fujian Province $\left(23^{\circ} 55^{\prime} \mathrm{N}, 117^{\circ} 26^{\prime} \mathrm{E}\right)$, and Leizhou Bay in the city of Leizhou, Guangdong Province $\left(20^{\circ} 56^{\prime} \mathrm{N}, 110^{\circ} 10^{\prime} \mathrm{E}\right)$. Both sites are tidal wetlands with semi-diurnal tides where mangroves and S. alterniflora occur sympatrically. Zhangjiang Estuary is well within the geographic range of K. obovata, but is close to the northern distribution limits of A. marina and S. apetala [55]. Leizhou Bay is near the southern distribution limit of $K$. obovata but well within the geographic ranges of $A$. marina and $S$. apetala.
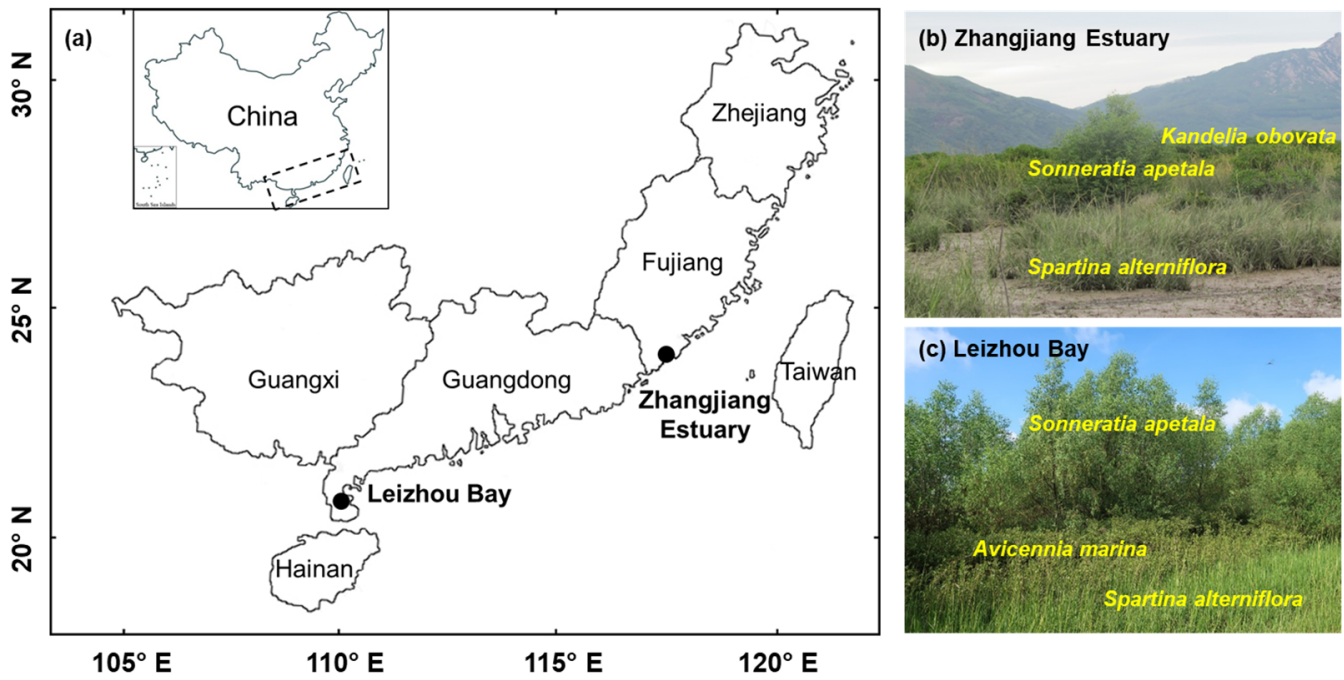

Figure 1. The study sites. (a) Map of southern China, showing the locations of the two study sites. Photographs of vegetation at (b) Zhangjiang Estuary, showing an individual Sonneratia apetala plant ( $\sim 3$ years old) growing amid native mangroves and Spartina alterniflora, and (c) Leizhou Bay, showing a large stand of Sonneratia apetala plants (4 5 years old and reproductive) encroaching upon native mangroves, with Spartina alterniflora in the forefront of the photograph.

The annual average temperature at Zhangjiang Estuary is $21.4^{\circ} \mathrm{C}$, with the highest monthly temperature of $29.5^{\circ} \mathrm{C}$ in August and the lowest monthly temperature of $13.3^{\circ} \mathrm{C}$ in January. The average annual precipitation is $1308 \mathrm{~mm}$, most of which occurs from April to September. We worked at a mesohaline site along the estuary where the water column salinity averages 18 PSU, and the mean tide range is $2.32 \mathrm{~m}$. Nitrogen content in the sediment averages $0.12 \%[49,55]$. Vegetation at the site is dominated by the mangrove K. obovata, which grows up to $7 \mathrm{~m}$ tall in the upper intertidal, with patches of vigorous A. marina (3 4 $\mathrm{m}$ tall) and abundant and vigorous stands of S. alterniflora at intermediate intertidal elevations (Figure 1b, Supplementary Table S1). S. alterniflora was first present in the 1990s [14] and has not completely colonized all the available habitat, so there are some patches of open mudflat scattered throughout the coalescing stand of S. alterniflora [56]. S. apetala was planted on the coast near the mouth of the estuary in 2006 and has since spread into the estuary. We first noticed it at the mesohaline site in 2010 [37].

Leizhou Bay is near the current southern limit of S. alterniflora in China [57]. The average temperature at Leizhou Bay is $23.1{ }^{\circ} \mathrm{C}$, with the highest monthly temperature of $32.8^{\circ} \mathrm{C}$ in July and the lowest monthly temperature of $16.5{ }^{\circ} \mathrm{C}$ in January. The average annual precipitation is $1646 \mathrm{~mm}$, most of which occurs from May to September. The water column salinity averages $22 \mathrm{PSU}$, and the mean tide range is $2.49 \mathrm{~m}$. Nitrogen content in the sediment averages $0.04 \%$ [49]. The vegetation is dominated by the non-native mangrove $S$. apetala, which was planted in 1995 [43], with stands of short 
(1 3 $\mathrm{m}$ tall) A. marina and patches of short ( $3 \mathrm{~m}$ tall) K. obovata interspersed throughout (Figure 1c, Supplementary Table S1). A large stand and multiple smaller patches of low-stature S. alterniflora occur at intermediate elevations, and a large mudflat at lower elevations. S. alterniflora was first present at this site in 2006 [57].

\subsection{Transplant Experiment to Evaluate Early Establishment of Mangroves}

At both sites, we transplanted three species of mangrove (K. obovata, A. marina, S. apetala) into three habitats (native mangroves, $S$. alterniflora, and unvegetated mudflat). The nature of the habitats differed between the two sites. At Zhangjiang Estuary, the mangrove habitat was dominated by K. obovata, and the $S$. alterniflora habitat supported vigorous growth (height, $189 \pm 4 \mathrm{~cm}$ (mean $\pm \mathrm{SE}$ ), aboveground biomass, $2592 \pm 186 \mathrm{~g} \mathrm{~m}^{-2}$ ). At Leizhou Bay, the mangrove habitat was dominated by native A. marina, and the S. alterniflora habitat was less productive (height, $102 \pm 13 \mathrm{~cm}$ (mean \pm SE), aboveground biomass, $1297 \pm 91 \mathrm{~g} \mathrm{~m}^{-2}$ ). We established six $2 \mathrm{~m} \times 2 \mathrm{~m}$ plots in each habitat at each site-plots within a habitat were at least $5 \mathrm{~m}$ apart, and the three groups of plots were $\sim 40 \mathrm{~m}$ apart. At each site, the mudflat plots were lowest in elevation and the mangrove plots were highest in elevation, with a total elevational range of $\sim 20 \mathrm{~cm}$. Since we worked in the existing habitats at each site, it was not possible to intersperse plots representing different habitats, or to standardize elevation.

We transplanted three seedlings of each mangrove species into each plot on 24 March 2018 in Leizhou Bay and 4 April 2018 in Zhangjiang Estuary. The three species differ in propagule phenology, K. obovata is viviparous, A. marina is cryptoviviparous, and S. apetala is non-viviparous, but we chose to transplant them on the same dates so that they would experience the same abiotic conditions and in order to standardize the initial size. Propagules of K. obovata were collected from trees near the site in spring, were $20.1 \pm 0.5 \mathrm{~cm}$ (mean \pm SE) in length, and were collected and planted on the same day. Seedlings of A. marina and S. apetala were purchased from a commercial nursery (propagules of these two species matured in autumn, then were cultivated in the nursery, which was located in the intertidal habitat and near to our study site), and were $\sim 6$ months old when planted. A. marina seedlings were $20.1 \pm 1.5 \mathrm{~cm}$ (mean $\pm \mathrm{SE}$ ) tall, and $S$. apetala seedlings were $14.5 \pm 0.3 \mathrm{~cm}$ (mean $\pm \mathrm{SE}$ ) tall when planted. Both had a root ball of $\sim 6 \mathrm{~cm} \times 6 \mathrm{~cm} \times 10 \mathrm{~cm}$ when planted. We monitored seedling survival every month, and measured the height of each surviving seedling at the end of the second growing season in October 2019. Seedlings that died were omitted from analyses of height. For each species, we averaged plant height, relative growth rate, calculated as [ $\operatorname{Ln}($ final size) $-\operatorname{Ln}($ initial size $)] /\left(t_{1}-t_{0}\right)$, where $t_{0}$ and $t_{1}$ are the time in months when the experiment started and ended within each plot, and used plots as the unit of replication. Data on mangrove performance were analyzed using threeway ANOVA, with site, species, and habitat as fixed factors. Due to the high mortality of some species in some habitats, we used individual one-way ANOVA and Tukey's HSD comparisons to compare the relative growth rate and height of surviving mangrove seedlings among species for each habitat at each site for which we had sufficient replication.

\subsection{Effects of Herbivory}

One cause of mortality to seedlings was herbivory. We measured herbivory by rodents (visible chewing damage to the stem) every month, and calculated the percentage of seedlings damaged by rodents in each plot over the course of the experiment. If the mangrove stem was grazed completely through, and the plant died within a month, we attributed mortality to rodent grazing. We measured herbivory by leaf-chewing insects (percent of leaves with any chewing damage) in September 2018, at the end of the growing season. We did not measure insect herbivory in 2019 because many of the mangrove seedlings had died, so the data were less informative. We averaged the percentage of leaves grazed by insects across the live seedlings in each plot. If insects fed on $>90 \%$ of the leaves on a plant, and the plant subsequently died, we attributed mortality to insect 
herbivory. Data on herbivory to mangroves were analyzed using three-way ANOVA, with site, species, and habitat as fixed factors.

\subsection{Abiotic Factors}

To characterize the abiotic conditions in each treatment at each site, we measured sediment water content and porewater salinity every two months between March 2018 and October 2019. Water content was measured gravimetrically by taking sediment samples (0 to $10 \mathrm{~cm}$ depth) from each plot and weighing them before and after drying. Porewater salinity was measured by rehydrating the dried sediment samples in a known volume of fresh water, measuring the salinity of the supernatant, and back-calculating to the original porewater salinity [58].

We measured light availability daily for two weeks every two months between March 2018 and October 2019. Light availability was measured using HOBO loggers (Pendant temp/light UA-002-64) deployed $30 \mathrm{~cm}$ above the sediment surface that logged Lux every 10 minutes ( $n=3$ per habitat type). For light availability, we averaged data from 11 a.m. to 2 p.m. on each day, deleting observations where the sensor was submerged at high tide. We monitored nighttime air temperature from December 2018 to February 2019, focusing on the winter temperatures because mangrove survival is related to winter minimum temperatures, with steep threshold responses that vary among species [8]. Nighttime air temperature was measured using HOBO loggers (Pendant temp UA-001-64) tied to PVC pipes at $30 \mathrm{~cm}$ above the sediment surface. We excluded daytime temperatures as direct solar insolation may lead to erroneous readings on unshielded HOBO loggers [20], and in any case, we were interested in minimum temperatures, which occurred at night. Hence, we calculated nightly (7 p.m.-7 a.m.) minimum temperatures from December 2018 to February 2019 for each habitat at each site. Abiotic data were analyzed using two-way ANOVA, with site and habitat as fixed factors.

\subsection{Relative Importance of Biotic and Abiotic Factors}

In order to determine the relative importance of the different biotic (mortality assigned to herbivory by rodents and insects) and abiotic (sediment water content, sediment porewater salinity, light intensity, temperature of the coldest month) factors on survival of the three mangrove species across the two sites (Leizhou Bay and Zhangjiang Estuary), we used a best subsets linear regression (Supplementary Table S2) to obtain the best regression models for variation in survival for each species. All analyses were performed using $\mathrm{R}$ (version 3.5.2) [59].

\section{Results}

\subsection{Transplant Experiment to Evaluate Early Establishment of Mangroves}

Final survival differed among species, habitats, and sites (Figure 2, Supplementary Table S3). K. obovata survived well at Leizhou Bay, especially in the mangrove and mudflat habitats, but had very low survival in Zhangjiang Estuary. A. marina survived well in the mudflat in Zhangjiang Estuary, but had very low survival in the mangrove (K. obovata) habitat at Zhangjiang Estuary and in the cordgrass habitat at Leizhou Bay. S. apetala survived well in all habitats at Leizhou Bay, but poorly in the mangrove (K. obovata) and cordgrass habitat at Zhangjiang Estuary.

For surviving plants, relative growth rates of $S$. apetala were higher than those of the two native mangroves in all habitats at both sites (Figure 3a,b, Supplementary Table S4). As a result, S. apetala grew taller than the S. alterniflora canopy in the cordgrass habitat at Leizhou Bay over only two growing seasons (Figure 3c,d, Supplementary Table S5).

\subsection{Effects of Herbivory}

The percentage of stems grazed by rodents differed among species, habitats, and sites (Figure 4, Supplementary Table S6). Rodent grazing was high (>70\%) for K. obovata in all habitats in Zhangjiang Estuary, moderate for K. obovata in all habitats in Leizhou Bay, and 
high $(100 \%)$ for A. marina in the mudflat at Zhangjiang Estuary. Rodent grazing was low or zero for $S$. apetala in all habitats at both sites. Almost all (67 100\%, depending on the site and habitat) of the K. obovata grazed by rodents died, but almost all of the $A$. marina grazed by rodents survived (Supplementary Figure S1, Table S7). Almost all of the rodent grazing occurred in December 2018-January 2019 at Zhangjiang Estuary and in April 2018 and April 2019 at Leizhou Bay (data not shown).
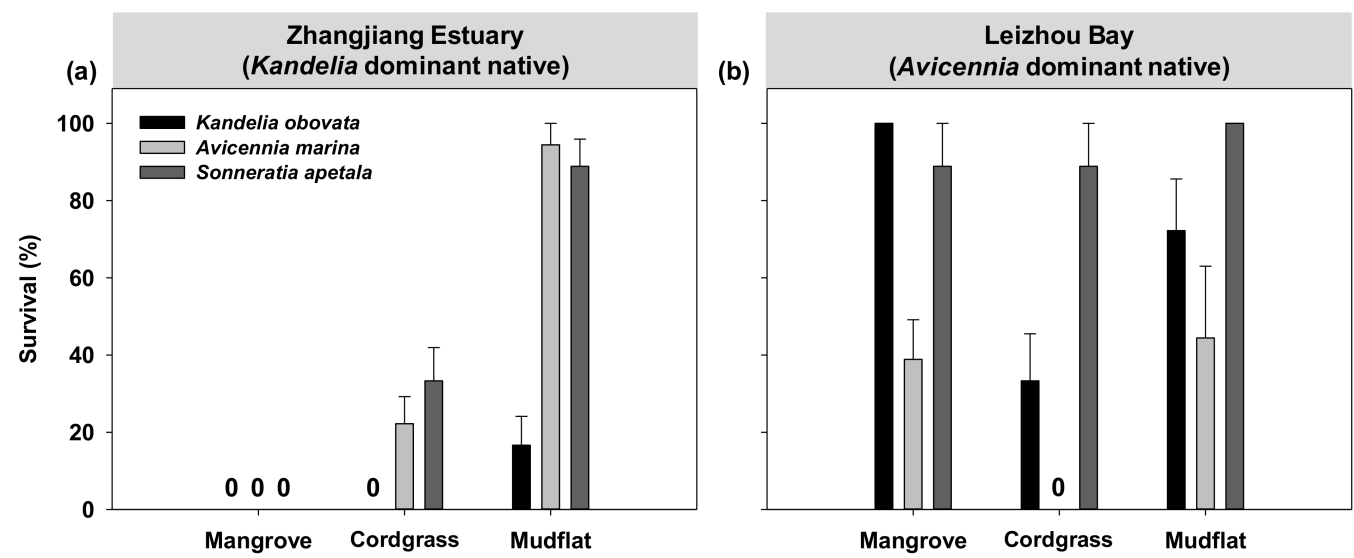

Figure 2. Seedling survival over two growing seasons in three habitats in (a) Zhangjiang Estuary and (b) Leizhou Bay. Data are means + SE ( $n=6$ per treatment). All main effects (site, species, habitat) and all two-way interactions affected mangrove survival (Supplementary Table S3).
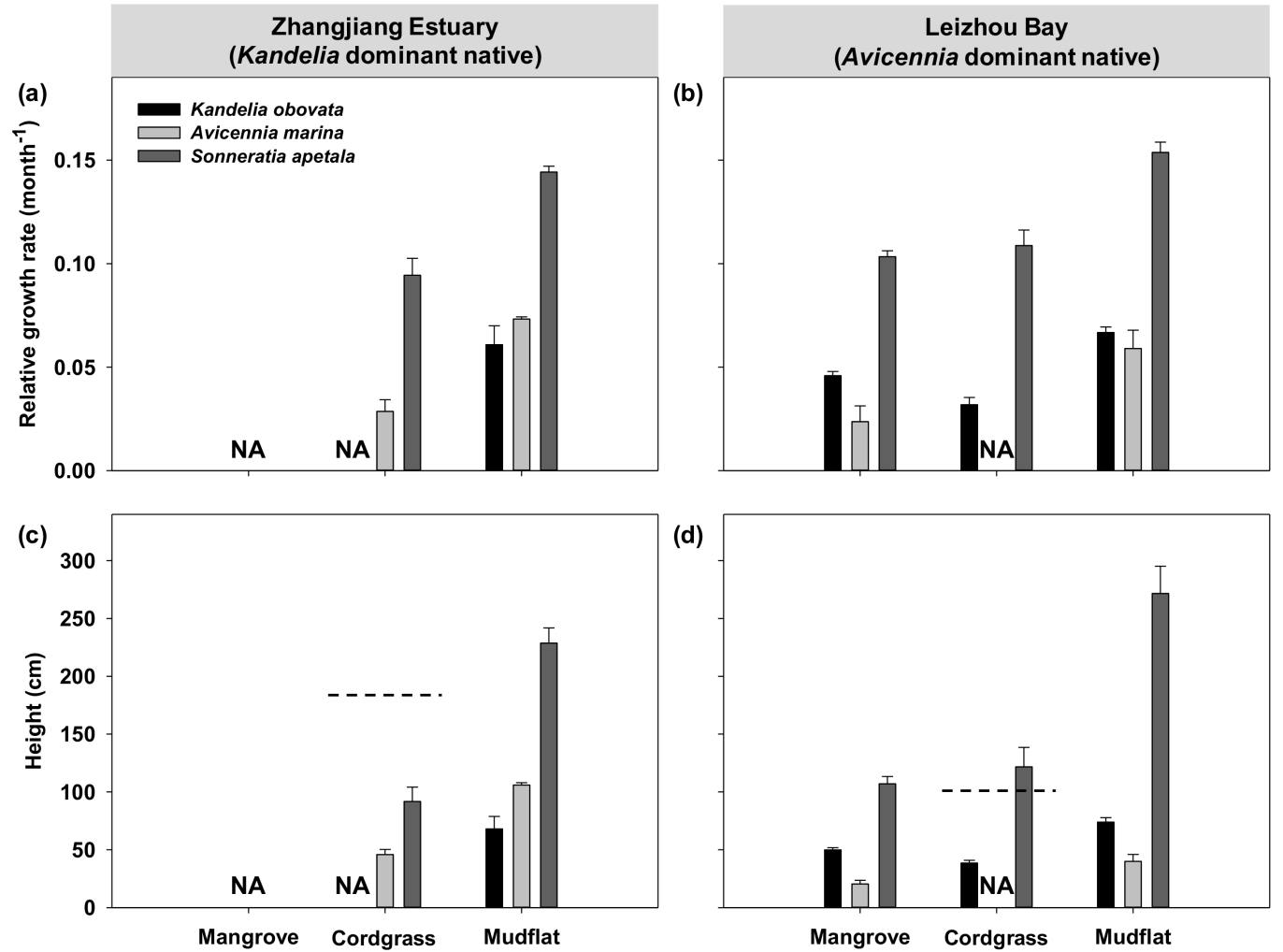

Figure 3. Relative growth rate $(\mathbf{a}, \mathbf{b})$ and height $(\mathbf{c}, \mathbf{d})$ of surviving seedlings at the end of two growing seasons in three habitats in Zhangjiang Estuary and Leizhou Bay. Data are means + SE $(n=3 \sim 6$ per treatment). NA = data not available because all the seedlings died. The dashed lines indicate the height of the Spartina alterniflora canopy at each site. Growth rates and height were different among species in each habitat at each site (Supplementary Tables S2 and S3) except for the mangrove habitat in Zhangjiang Estuary, where all seedlings died. 

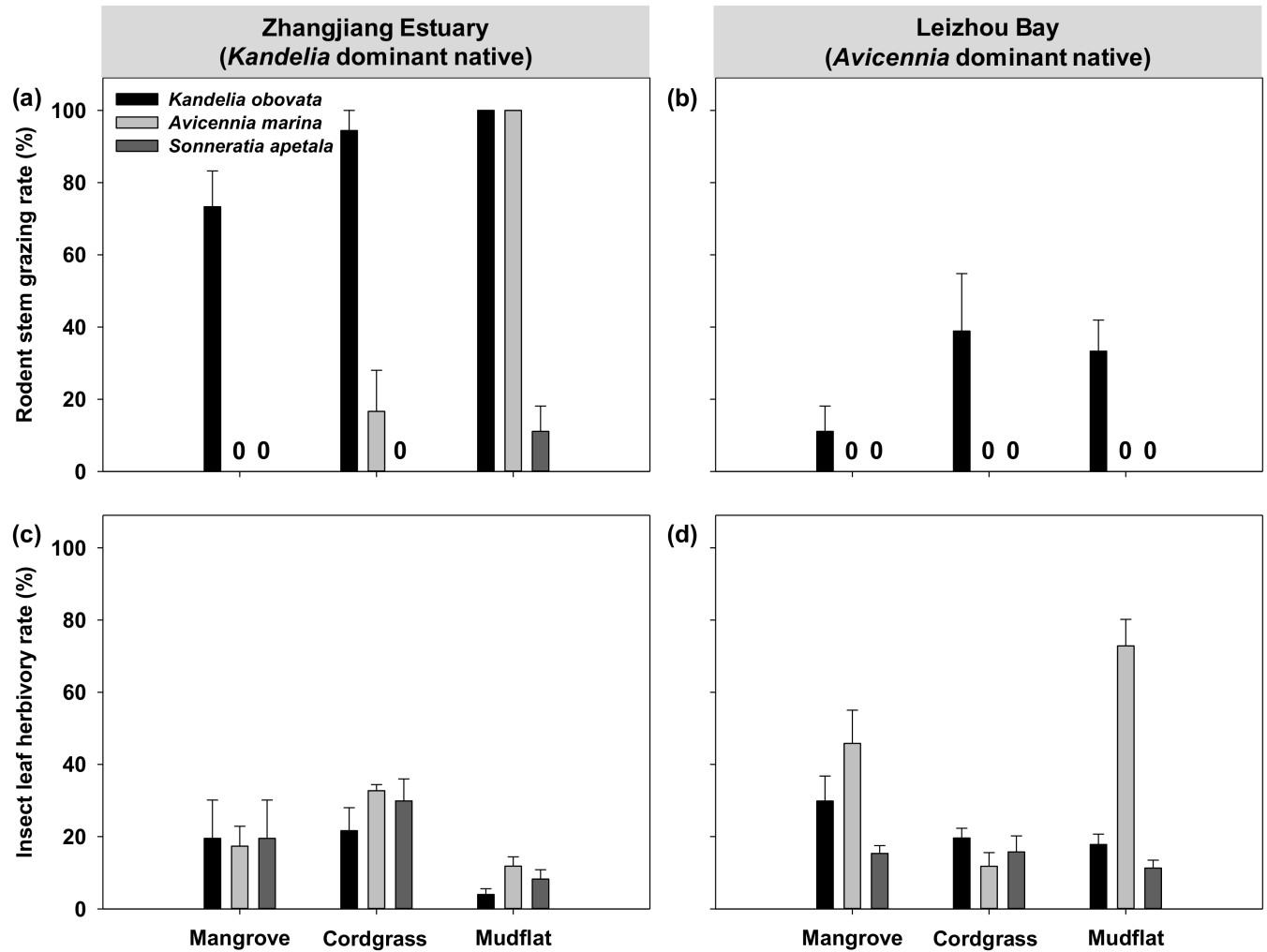

Figure 4. Percentage of stems grazed by rodents in three habitats in (a) Zhangjiang Estuary and (b) Leizhou Bay, and percentage of leaves grazed by insects in three habitats in (c) Zhangiiang Estuary and (d) Leizhou Bay. Data are means + SE ( $n=6$ per treatment). All the main effects (site, species, habitat) interacted to affect grazing by both rodents and insects (Supplementary Table S6).

The percentage of leaves grazed by insects differed among species and sites, but did not differ among habitats (Figure 4, Supplementary Table S6). Herbivory rates were higher for A. marina than for the other two mangrove species, especially at the Leizhou Bay site. All of the K. obovata and all of the S. apetala grazed by insects survived, but $38 \sim 100 \%$ of the A. marina grazed by insects at Leizhou Bay died (Supplementary Figure S1, Table S7).

\subsection{Effects of Abiotic Factors}

The major abiotic difference between habitats was light intensity (Table 1, Supplementary Table S8). Light intensity was highest in the unvegetated mudflat habitat, intermediate in the cordgrass habitat, and lowest in the mangroves, and was lower at Zhangjiang Estuary than at Leizhou Bay, especially in the vegetated habitats. The temperature of the coldest month was higher at Leizhou Estuary, but did not differ among habitats. Sediment water content was highest at Zhangjiang Estuary, and differed slightly among habitats. Porewater salinity was highest at Leizhou Bay, but did not differ among habitats. We saw no evidence of plants dying from stress due to sediment water content (drought or flooding), which in any case did not differ greatly among habitats or sites.

\subsection{Effects of Competition}

The pattern of residual mortality was consistent due to competition from other species (Supplementary Figure S1, Table S7). For mangroves that were not heavily grazed by rodents or insects, mortality was high for all three species in the mangrove habitat in Zhangjiang Estuary, and moderate for A. marina in the mangrove habitat in Leizhou Bay (Supplementary Figure S1). In the absence of other obvious causes, we assumed that this mortality was due to competition with existing adult mangroves for light or nutrients. Mortality was also high for all three species in the cordgrass habitat in Zhangjiang Estuary, where none of the mangrove species outgrew the S. alterniflora canopy, and for K. obovata and 
A. marina in the cordgrass habitat in Leizhou Bay, where these two species did not outgrow the $S$. alterniflora canopy but $S$. apetala did. In the absence of other obvious causes, we assumed that this mortality was due to competition with $S$. alterniflora for light or nutrients.

Table 1. Abiotic factors in three habitats in Zhangjiang Estuary and Leizhou Bay. Data are means \pm SE (light intensity and air temperature of the coldest month: $n=3$ per habitat at each site, sediment water content and sediment porewater salinity: $n=35 \sim 60$ per habitat at each site). Tukey's HSD significances (at the level of $p<0.05$ ) are shown by different letters.

\begin{tabular}{ccccc}
\hline Source of Variance & $\begin{array}{c}\text { Light Intensity } \\
\left(\times \mathbf{1 0}^{\mathbf{3}} \mathbf{L u x}\right)\end{array}$ & $\begin{array}{c}\text { Temperature of the } \\
\text { Coldest Month }\left({ }^{\circ} \mathbf{C}\right)\end{array}$ & $\begin{array}{c}\text { Sediment Water } \\
\text { Content }(\mathbf{\%})\end{array}$ & $\begin{array}{c}\text { Sediment Porewater } \\
\text { Salinity (PSU) }\end{array}$ \\
\hline $\begin{array}{c}\text { Zhangjiang Estuary } \\
\text { Mangrove }\end{array}$ & $7.0 \pm 1.1 \mathrm{e}$ & $12.3 \pm 0.1 \mathrm{~b}$ & $49.0 \pm 0.2 \mathrm{a}$ & $18.9 \pm 1.0 \mathrm{ab}$ \\
Cordgrass & $25.7 \pm 4.3 \mathrm{~d}$ & $12.3 \pm 0.1 \mathrm{~b}$ & $52.0 \pm 0.5 \mathrm{a}$ & $17.6 \pm 0.8 \mathrm{~b}$ \\
$\quad \begin{array}{c}\text { Mudflat } \\
\text { Leizhou Bay }\end{array}$ & $83.9 \pm 1.3 \mathrm{~b}$ & $12.1 \pm 0.2 \mathrm{~b}$ & $51.7 \pm 0.4 \mathrm{a}$ & $18.4 \pm 0.9 \mathrm{ab}$ \\
Mangrove & $37.7 \pm 2.9 \mathrm{~d}$ & $16.3 \pm 0.3 \mathrm{a}$ & $34.1 \pm 0.8 \mathrm{c}$ & $21.6 \pm 1.0 \mathrm{a}$ \\
Cordgrass & $57.6 \pm 4.8 \mathrm{c}$ & $16.4 \pm 0.1 \mathrm{a}$ & $40.7 \pm 1.1 \mathrm{~b}$ & $21.8 \pm 0.8 \mathrm{a}$ \\
Mudflat & $105.0 \pm 4.8 \mathrm{a}$ & $16.6 \pm 0.0 \mathrm{a}$ & $28.2 \pm 0.5 \mathrm{~d}$ & $19.1 \pm 0.8 \mathrm{ab}$ \\
\hline
\end{tabular}

\subsection{Relative Importance of Biotic and Abiotic Factors}

The best regression models indicated that, for K. obovata, rodent herbivory, sediment porewater salinity, and light intensity were strong predictors of survival across both study sites, with rodent herbivory being the strongest driver (Table 2). For A. marina, rodent herbivory, insect herbivory, light intensity, and temperature were strong predictors for survival across both study sites, with light intensity being the strongest driver. In this model, higher temperatures were associated with lower survival, which is biologically implausible unless it reflects some other factor (perhaps increased herbivory or competition) that was not fully described by other variables in the regression model. For S. apetala, light intensity and temperature were strong predictors for survival across both study sites, with light intensity being the strongest driver. Overall, herbivory by rodents and insects was important for the two native mangroves, but not for the non-native S. apetala. Light intensity was important for both native and non-native mangroves.

Table 2. Results of the best multiple regression models for survival of three mangrove species across both sites. Significant $p$-values $(p<0.05)$ are in bold. The best models were chosen based on $R^{2}$ and Mallow's $\mathrm{Cp}$ and included some variables that were not statistically significant. Other reasonable models are shown in Supplementary Table S2.

\begin{tabular}{|c|c|c|c|c|c|}
\hline Species & Variable & Coef. & SE & $t$ & $p$ \\
\hline Kandelia obovata & Rodent & -0.91 & 0.07 & -9.62 & $<0.0001$ \\
\hline \multirow[t]{2}{*}{$\left(\right.$ Mallow's Cp $=5.49$, Adj $\left.R^{2}=0.82\right)$} & Sediment porewater salinity & -0.08 & 0.09 & -0.89 & 0.38 \\
\hline & Light intensity & 0.12 & 0.08 & 1.51 & 0.14 \\
\hline Avicennia marina & Rodent & -0.18 & 0.12 & -1.49 & 0.14 \\
\hline \multirow[t]{3}{*}{$\left(\right.$ Mallow's Cp $=3.75$, Adj $\left.R^{2}=0.54\right)$} & Insect & -0.33 & 0.14 & -2.39 & 0.02 \\
\hline & Light intensity & 0.81 & 0.13 & 6.34 & $<0.0001$ \\
\hline & Temperature & -0.36 & 0.14 & -2.48 & 0.02 \\
\hline Sonneratia apetala & Light intensity & 0.001 & 0.0001 & 5.09 & $<0.0001$ \\
\hline$\left(\right.$ Mallow's Cp $=5.36$, Adj $\left.R^{2}=0.72\right)$ & Temperature & 7.48 & 2.14 & 3.48 & 0.001 \\
\hline
\end{tabular}

\section{Discussion}

Our results indicate that establishment of native mangrove seedlings on the southern coast of China is limited by herbivory and competition. Worldwide, some communities have "biotic resistance" to non-native species, where natives suppress the non-native species. We found the opposite: native mangrove seedlings suffered strong herbivory and competition, however, the non-native mangrove $S$. apetala was less affected. In particular, 
we found that the non-native mangrove $S$. apetala can survive and outcompete invasive S. alterniflora over only two growing seasons in Leizhou Bay, but that both native mangroves survived poorly in the Spartina stands. Escape from herbivory and fast growth may drive the quick expansion of non-native S. apetala in China. As a result, it is likely that the coastal plant community will be increasingly dominated by non-native $S$. apetala.

\subsection{Herbivory by Rodents and Insects Mediates Mangrove Establishment}

Mangroves often suffer extensive mortality due to consumers at the propagule [60,61] and seedling [31,32] stages. Adult mangroves also experience considerable herbivory at times [62,63], but this is rarely severe enough to cause mortality or change plant species composition. This is consistent with results from other plant species: in general, juvenile stages are more vulnerable to consumers than are adults [64]. We found that grazing by the native rodent $R$. losea and insects strongly suppressed native mangrove growth and survival at the sites we studied. In particular, grazing by rodents especially affected $K$. obovata in Zhangjiang Estuary, where it was the dominant native mangrove. Grazing by insects especially affected $A$. marina in Leizhou Bay, where it was the dominant native mangrove.

Herbivores can have strong deleterious effects on plant growth, reproduction, and survival $[65,66]$. A number of herbivore taxa are known to affect the distribution and abundance of intertidal plants, with most research focusing on crabs, insects, birds, and large mammals in salt marshes [62,67]. Historically, small mammal herbivores were thought to play a minor role in structuring saltmarsh plant communities [68,69], but a number of exceptions are known. For example, herbivory by meadow voles (Microtus pennsylvanicus) and deer mice (Peromyscus leucopus) influences plant species interactions in New England [70], and grazing by the introduced rodent nutria, Myocastor coypus, affects the distribution and productivity of intertidal plants in Louisiana [71]. Here, we show that small mammal grazing plays an important role in the early establishment of mangroves at two study sites in southern China (Supplementary Figure S2).

We observed grazing by $R$. losea on mangrove seedlings at two sites that were $820 \mathrm{~km}$ apart in southern China, indicating that herbivory by rodents on mangroves is widespread. $R$. losea is widely distributed in southeast China, where it causes significant damage to crops [53]. It was previously known to nest in mangrove canopies above the high-tide level, using leaves and branches of mangrove plants as construction materials [52]. Now that the introduced $S$. alterniflora has become widespread along the Chinese coast, $R$. losea preferentially builds its nests with leaves and stems of S. alterniflora along the mangroveS. alterniflora ecotone [29]. We did note, however, that rat nests were more common at Zhangjiang Estuary, where S. alterniflora stands were widespread and vigorous, than at Leizhou Bay, where S. alterniflora stands were smaller and shoots were shorter (authors' personal observations). Consistent with this, grazing by rats on mangrove seedlings was greater at Zhangjiang Estuary than at Leizhou Bay. R. losea preferred to feed on native versus non-native mangrove species. In particular, rodent grazing heavily suppressed the survival of native $K$. obovata, because rodents fed both on the tips of newly planted propagules and on the stems of growing seedlings. A. marina was less affected, because rodents only grazed the more tender, upper stems of the plants, and not the tougher, main stem, which allowed the mangroves to resprout after grazing (Supplementary Figure S3). In addition, the fact that seedlings of $A$. marina possessed a $6 \mathrm{~cm} \times 6 \mathrm{~cm} \times 10 \mathrm{~cm}$ root ball at the start of the experiment might have helped them recover from grazing compared to K. obovata, which did not have a root ball at the beginning of the experiment; however, it would not explain the differences in grazing location. Rodents largely avoided the nonnative $S$. apetala seedlings. The proximate reasons why $S$. apetala is mostly avoided by the rodents are not known, but the result is that rodent grazing suppresses regeneration of the native mangrove species, but not the non-native species.

Both the native and non-native mangroves suffered some insect herbivory in our study (Supplementary Figure S4); however, insect folivory was highest on A. marina at the lower-latitude site of Leizhou Bay, where it was the dominant native species. This latitu- 
dinal pattern was consistent with general biogeography theory, predicting that herbivory pressure increases with decreasing latitude, and data from both salt marshes and mangroves showing that herbivory is higher at lower latitudes [63,72,73]. Leaves of $A$. marina have a higher nitrogen content and lower tannin content than leaves of many other mangrove species [2,50], which may explain why this species was preferentially grazed by insects. In contrast, leaves of $S$. apetala have a higher tannin content than leaves of native mangroves [74], which may explain why the non-native species was avoided.

These results are consistent with the "enemy release hypothesis" [25] for S. apetalathat it has escaped its native herbivores in the introduced range, and that this loss of herbivory is one factor that contributes to its success. We did not directly compare herbivory on $S$. apetala between the native and introduced ranges, so we cannot directly evaluate this hypothesis, but it is known that $S$. apelata suffers some herbivory by Orgyia osseata and Streblote siva in its native range [75], and we observed little to no herbivory on it in China.

\subsection{Competition from Native Mangroves and Non-Native Cordgrass Mediates Mangrove Establishment}

In addition to herbivory, mangrove seedlings were strongly affected by competition. Mangrove seedlings, similar to small plants in general, face intense competition for light from their taller neighbors [76]. None of the mangrove seedlings that we planted in stands of K. obovata (e.g., mangrove stands at Zhangjiang Estuary) survived, likely because this habitat had the lowest light availability (10\% of ambient light) due to shading by large K. obovata trees (Supplementary Table S2). Survival gradually increased in other habitats with more light availability. We note that these plants may have also been competing for sediment nutrients, which we did not measure. Regardless, competition seems to be strong for mangrove seedlings, such as those studied here, but weak once mangroves outgrow the canopy of their neighbors [77] (authors' personal observation).

We found that the non-native grass $S$. alterniflora strongly suppressed the growth and survival of mangrove seedlings. This result is consistent with the general finding that invasive non-native species often have strong competitive impacts on native species [26]. S. alterniflora coexists with mangroves in parts of its native range in the United States and in parts of its introduced range in China. In both cases, a number of studies have shown that it competes with mangrove seedlings. For example, in its native range, S. alterniflora impedes the growth of black mangrove (A. germinans) seedlings $[78,79]$. Similarly, in China, $S$. alterniflora significantly reduces the survival and growth of native mangrove seedlings [14,37]. Consistent with these past results, S. alterniflora strongly suppressed regeneration of the two native mangroves at the two sites we studied in China [14,37,57]. As with herbivory, however, the effect on S. apetala was weaker.

Overall, survival of the non-native mangrove $S$. apetala was higher than that of native mangroves. S. apetala mortality from abiotic factors and competition, however, was higher than that of the native mangroves at the high-latitude site (Zhangjiang Estuary), likely because $S$. apetala has a tropical distribution in its native range and is therefore sensitive to low temperatures in its introduced range in China [42,51]. The average low temperature during winter in Zhangjiang Estuary was $<12.5^{\circ} \mathrm{C}$ (average of nighttime temperatures over the coldest month), which is similar to the temperature limit of $13.6^{\circ} \mathrm{C}$ (average of $24 \mathrm{~h}$ temperatures over the coldest month) reported for $S$. apetala in its native range [75]. Lower survival of non-native $S$. apetala in vegetated habitats likely occurred because plants were simultaneously suffering from low temperatures and low light intensity.

We noted a synergistic interaction between grazing and light availability in suppressing the establishment of native mangroves. When grazing and shading were both present, as in the mangrove understory and the S. alterniflora habitat, establishment of native mangroves was very poor. In contrast, the non-native mangrove $S$. apetala was able to establish in mangrove (Leizhou Bay) and S. alterniflora habitats in both sites. This synergistic interaction between herbivory and competition for light is in broad agreement with a growing body of literature showing that consumer pressure can interact synergistically with environmental stressors $[29,47,62]$. Our findings highlight the importance of considering multiple 
factors that may covary when assessing the strength of biotic resistance mechanisms, especially considering that herbivory and competition are universal processes that operate across ecosystems and that naturally interact with each other [80].

\subsection{Novel Interaction between Non-Native Species in Southern China}

China has the largest S. alterniflora invasion in the world [39]. S. alterniflora has aggressively invaded mudflats and disturbed stands of native mangroves along the southern coasts of China during the last two decades [38,45], forming a mangrove-salt marsh ecotone across more than $9^{\circ}$ of latitude. S. alterniflora competes with seedlings of native mangroves such that native mangroves can rarely regenerate in Spartina stands [11,14,37]. At the same time, however, S. alterniflora cannot invade intact stands of native mangroves [29,47], so both the non-native grass and the native mangroves can coexist in the absence of disturbance. The non-native mangrove $S$. apetala, however, alters this outcome. S. apetala grows rapidly and can outcompete both the invasive grass $S$. alterniflora and native scrub mangroves over two or three growing seasons $[37,43,48]$. As a result, $S$. apetala can be used to control the $S$. alterniflora invasion [48], but the end result is to replace one non-native species with another, and to replace native mangroves with a non-native mangrove. S. apetala had a higher growth rate than the native mangroves-this rapid growth rate is why this species was deliberately introduced into China for afforestation projects [42,45]. Although S. apetala was attractive to managers because its rapid growth led to impressive "afforestation" statistics, its introduction to China is likely to transform the native mangroves and intertidal $S$. alterniflora grasslands into low-diversity stands of non-native mangrove across the entire intertidal area. Our results suggest that coastal managers should avoid planting non-native S. apetala as a strategy either for restoration or for controlling the Spartina invasion.

\section{Conclusions}

Our study was the first, to our knowledge, to look at the role of mammal and insect herbivores in mediating the early establishment of both native and non-native mangrove species. Meanwhile, we considered how the vigorous invasion of $S$. alterniflora influenced the establishment of both native and non-native mangrove seedlings. Our findings showed that successful establishment of $S$. apetala was facilitated by release from natural enemies (the opposite of biotic resistance) and by fast growth that allowed it to outcompete neighboring plants. Our results provide new insights into how herbivory, competition, and abiotic factors interact to mediate the establishment of native and non-native mangroves, and also help forecast the future of coastal ecosystems in southern China.

Supplementary Materials: The following supporting information can be downloaded at: https: //www.mdpi.com/article/10.3390/f13020192/s1, Figure S1: Causes of mortality of seedlings of the three mangrove species. Figure S2: The native rat Rattus losea and its nest in Zhangjiang Estuary and in Leizhou Bay. Figure S3: Native mangrove seedlings that were grazed by rodents. Figure S4: Native and non-native mangrove leaves grazed by insects. Table S1: Density and vegetation structure of two native mangrove forests and Spartina altetniflora in Zhangjiang Estuary and Leizhou Bay. Table S2: Results of the best subset linear regression using up to six independent variables to predict survival of Kandelia obovata, Avicennia marina, and Sonneratia apetala in Leizhou Bay and Zhangjiang Estuary. Tables S3-S5: Summary of ANOVA tables examining the effects of site, species, habitat, and the interaction between them on plant survival, relative growth rate, and height in Zhangjiang Estuary and Leizhou Bay. Tables S6-S8: Summary of ANOVA tables examining the effects of site, species, habitat, and the interaction between them on the rodent stem grazing rate, the insect leaf herbivory rate, mortality by rodents, and competition and abiotic factors in Zhangjiang Estuary and Leizhou Bay.

Author Contributions: S.C.P. and Y.Z. designed the experiment and supervised the study; D.P., J.W., and Y.Z. conducted the experiment; D.P. and Y.Z. analyzed the data. All authors have read and agreed to the published version of the manuscript. 
Funding: This research was supported by the National Natural Science Foundation of China (Grant Nos. 31971500, 31770464, and 31470485), and the Fundamental Research Funds for the Central Universities of China (Grant No. 20720210075). S.C.P. was supported by the Texas Sea Grant (NA10OAR4170099). D.P. was supported by the China Scholarship Council (CSC) for study at the University of Houston.

Institutional Review Board Statement: Not applicable.

Informed Consent Statement: Not applicable.

Data Availability Statement: Not applicable.

Acknowledgments: We thank W. Liu, X. Chen, L. Li, and W. Han for help in the field. We thank L. Meng and K. Chen for taking drone images in the field. We thank C. Zhao for analyzing the UAV and Google earth data. We are grateful to the Zhangjiang Estuary and Mangrove National Nature Reserve, and Zhanjiang Mangrove National Nature Reserve for access to study sites and for their long-term support of our ecological research programs.

Conflicts of Interest: All authors declare that this research was finished without any commercial relationships and with no conflict of interest.

\section{References}

1. Lee, S.Y.; Primavera, J.H.; Dahdouh-Guebas, F.; McKee, K.; Bosire, J.O.; Cannicci, S.; Diele, K.; Fromard, F.; Koedam, N.; Marchand, C.; et al. Ecological role and services of tropical mangrove ecosystems: A reassessment. Glob. Ecol. Biogeogr. 2014, $23,726-743$. [CrossRef]

2. Tomlinson, P.B. The Botany of Mangroves, 2nd ed.; Cambridge University Press: New York, NY, USA, 2016.

3. Ward, R.D.; Friess, D.A.; Day, R.H.; Mackenzie, R.A. Impacts of climate change on mangrove ecosystems: A region by region overview. Ecosyst. Health Sustain. 2016, 2, e01211. [CrossRef]

4. Wang, W.; Fu, H.; Lee, S.Y.; Fan, H.; Wang, M. Can strict protection stop the decline of mangrove ecosystems in China? From rapid destruction to rampant degradation. Forests 2020, 11, 55. [CrossRef]

5. $\quad$ Friess, D.A.; Rogers, K.; Lovelock, C.E.; Krauss, K.W.; Hamilton, S.E.; Lee, S.Y.; Lucas, R.; Primavera, J.; Rajkaran, A.; Shi, S. The state of the world's mangrove forests: Past, present, and future. Annu. Rev. Environ. Resour. 2019, 44, 89-115. [CrossRef]

6. Ho, Y.-S.; Mukul, S.A. Publication performance and trends in mangrove forests: A bibliometric analysis. Sustainability 2021, 13, 12532. [CrossRef]

7. McKee, K.L.; Rogers, K.; Saintilan, N. Response of salt marsh and mangrove wetlands to changes in atmospheric $\mathrm{CO}_{2}$, climate and sea level. In Global Change and the Function and Distribution of Wetlands, 1st ed.; Middleton, B.A., Ed.; Springer: Dordrecht, The Netherlands, 2012; pp. 63-96.

8. Cavanaugh, K.C.; Kellner, J.R.; Forde, A.J.; Gruner, D.S.; Parker, J.D.; Rodriguez, W.; Feller, I.C. Poleward expansion of mangroves is a threshold response to decreased frequency of extreme cold events. Proc. Natl. Acad. Sci. USA 2014, 111, 723-727. [CrossRef]

9. Chen, L.; Wang, W.; Li, Q.Q.; Zhang, Y.; Yang, S.; Osland, M.J.; Huang, J.; Peng, C. Mangrove species' responses to winter air temperature extremes in China. Ecosphere 2017, 8, e01865. [CrossRef]

10. Biswas, S.R.; Biswas, P.L.; Limon, S.H.; Yan, E.; Xu, M.; Khan, M.S.I. Plant invasion in mangrove forests worldwide. For. Ecol. Manag. 2018, 429, 480-492. [CrossRef]

11. Chen, L. Invasive plants in coastal wetlands: Patterns and mechanisms. In Wetlands: Ecosystem Services, Restoration and Wise Use, 1st ed.; An, S., Verhoeven, J., Eds.; Springer: Cham, Switzerland, 2019; Volume 238, pp. 97-128.

12. Simberloff, D.; Martin, J.L.; Genovesi, P.; Maris, V.; Wardle, D.A.; Aronson, J.; Courchamp, F.; Galil, B.; García-Berthou, E.; Pascal, M.; et al. Impacts of biological invasions: What's what and the way forward. Trends Ecol. Evol. 2013, 28, 58-66. [CrossRef]

13. Guimarães Sampaio, J.A.; Gonçalves Reis, C.R.; Cunha-Lignon, M.; Nardoto, G.B.; Salemi, L.F. Plant invasion affects vegetation structure and sediment nitrogen stocks in subtropical mangroves. Mar. Environ. Res. 2021, 172, 105506. [CrossRef]

14. Zhang, Y.; Huang, G.; Wang, W.; Chen, L.; Lin, G. Interactions between mangroves and exotic Spartina in an anthropogenically disturbed estuary in southern China. Ecology 2012, 93, 588-597. [CrossRef] [PubMed]

15. Ren, H.; Guo, Q.; Liu, H.; Li, J.; Zhang, Q.; Xu, H.; Xu, F. Patterns of alien plant invasion across coastal bay areas in southern China. J. Coast. Res. 2014, 30, 448-455. [CrossRef]

16. Fourqurean, J.W.; Smith, T.J.; Possley, J.; Collins, T.M.; Lee, D.; Namoff, S. Are mangroves in the tropical Atlantic ripe for invasion? Exotic mangrove trees in the forests of South Florida. Biol. Invasions 2010, 12, 2509-2522. [CrossRef]

17. Saenger, P.; Bellan, M.F. The Mangrove Vegetation of the Atlantic Coast of Africa: A Review, 1st ed.; Université de Toulouse: Toulouse, France, $1995 ;$ pp. 1-62.

18. Demopoulos, A.W.J.; Fry, B.; Smith, C.R. Food web structure in exotic and native mangroves: A Hawaii-Puerto Rico comparison. Oecologia 2007, 153, 675-686. [CrossRef]

19. Devaney, J.L.; Lehmann, M.; Feller, I.C.; Parker, J.D. Mangrove microclimates alter seedling dynamics at the range edge. Ecology 2017, 98, 2513-2520. [CrossRef] 
20. Guo, H.; Weaver, C.; Charles, S.P.; Whitt, A.; Dastidar, S.; D’Odorico, P.; Fuentes, J.D.; Kominoski, J.S.; Armitage, A.R.; Pennings, S.C. Coastal regime shifts: Rapid responses of coastal wetlands to changes in mangrove cover. Ecology 2017, 98, 762-772. [CrossRef]

21. Saintilan, N.; Wilson, N.C.; Rogers, K.; Rajkaran, A.; Krauss, K.W. Mangrove expansion and salt marsh decline at mangrove poleward limits. Glob. Chang. Biol. 2014, 20, 147-157. [CrossRef]

22. Adams, J.B.; de Freitas, D.M.; Rogers, K.; Woodroffe, C.D. Estuaries and coastal wetlands of the southern hemisphere-An Overview. Estuar. Coast. Shelf Sci. 2021, 250, 107125. [CrossRef]

23. Theoharides, K.A.; Dukes, J.S. Plant invasion across space and time: Factors affecting nonindigenous species success during four stages of invasion. New Phytol. 2007, 176, 256-273. [CrossRef]

24. Eschtruth, A.K.; Battles, J.J. Assessing the relative importance of disturbance, herbivory, diversity, and propagule pressure in exotic plant invasion. Ecol. Monogr. 2009, 79, 265-280. [CrossRef]

25. Maron, J.L.; Vilà, M. When do herbivores affect plant invasion? Evidence for the natural enemies and biotic resistance hypotheses. Oikos 2001, 95, 361-373. [CrossRef]

26. Levine, J.M.; Adler, P.B.; Yelenik, S.G. A meta-analysis of biotic resistance to exotic plant invasions. Ecol. Lett. 2004, 7, 975-989. [CrossRef]

27. Kalisz, S.; Spigler, R.B.; Horvitz, C.C. In a long-term experimental demography study, excluding ungulates reversed invader's explosive population growth rate and restored natives. Proc. Natl. Acad. Sci. USA 2014, 111, 4501-4506. [CrossRef] [PubMed]

28. Pearson, D.E.; Potter, T.; Maron, J.L. Biotic resistance: Exclusion of native rodent consumers releases populations of a weak invader. J. Ecol. 2012, 100, 1383-1390. [CrossRef]

29. Zhang, Y.; Meng, H.; Wang, Y.; He, Q. Herbivory enhances the resistance of mangrove forest to cordgrass invasion. Ecology 2018, 99, 1382-1390. [CrossRef]

30. Stohlgren, T.J.; Schell, L.D.; Vanden Heuvel, B. How grazing and soil quality affect native and exotic plant diversity in rocky mountain grasslands. Ecol. Appl. 1999, 9, 45-64. [CrossRef]

31. Cannicci, S.; Burrows, D.; Fratini, S.; Smith, T.J.; Offenberg, J.; Dahdouh-Guebas, F. Faunal impact on vegetation structure and ecosystem function in mangrove forests: A review. Aquat. Bot. 2008, 89, 186-200. [CrossRef]

32. Langston, A.K.; Kaplan, D.A.; Angelini, C. Predation restricts black mangrove (Avicennia germinans) colonization at its northern range limit along Florida's gulf coast. Hydrobiologia 2017, 803, 317-331. [CrossRef]

33. Bakker, J.; Wilson, S. Competitive abilities of introduced and native grasses. Plant Ecol. 2001, 157, 117-125. [CrossRef]

34. Amsberry, L.; Baker, M.A.; Ewanchuk, P.J.; Bertness, M.D. Clonal integration and the expansion of Phragmites australis. Ecol. Appl. 2000, 10, 1110-1118. [CrossRef]

35. Fine, P.V.A. The invasibility of tropical forests by exotic plants. J. Trop. Ecol. 2002, 18, 687-705. [CrossRef]

36. Pranchai, A.; Jenke, M.; Vogt, J.; Grueters, U.; Yue, L.; Mehlig, U.; de Menezes, M.M.; Wagner, S.; Berger, U. Density-dependent shift from facilitation to competition in a dwarf Avicennia germinans forest. Wetl. Ecol. Manag. 2018, 26, 139-150. [CrossRef]

37. Peng, D.; Chen, L.; Pennings, S.C.; Zhang, Y. Using a marsh organ to predict future plant communities in a Chinese estuary invaded by an exotic grass and mangrove. Limnol. Oceanogr. 2018, 63, 2595-2605. [CrossRef]

38. An, S.; Gu, B.; Zhou, C.; Wang, Z.; Deng, Z.; Zhi, Y.; Li, H.; Chen, L.; Yu, D.; Liu, Y. Spartina invasion in China: Implications for invasive species management and future research. Weed Res. 2007, 47, 183-191. [CrossRef]

39. Strong, D.R.; Ayres, D.R. Ecological and evolutionary misadventures of Spartina. Annu. Rev. Ecol. Evol. Syst. 2013, 44, 389-410. [CrossRef]

40. Milbrandt, E.C.; Tinsley, M.N. The role of saltwort (Batis maritima L.) in regeneration of degraded mangrove forests. Hydrobiologia 2006, 568, 369-377. [CrossRef]

41. McKee, K.L.; Rooth, J.E.; Feller, I.C. Mangrove recruitment after forest disturbance is facilitated by herbaceous species in the Caribbean. Ecol. Appl. 2007, 17, 1678-1693. [CrossRef]

42. Liao, B.; Zheng, S.; Chen, Y.; Li, M.; Li, Y. Biological characteristics and ecological adaptability for non-indigenous mangrove species Sonneratia apetala. Chin. J. Ecol. 2004, 23, 10-15.

43. Ren, H.; Lu, H.; Shen, W.; Huang, C.; Guo, Q.; Li, Z.; Jian, S. Sonneratia apetala Buch.Ham in the mangrove ecosystems of China: An invasive species or restoration species? Ecol. Eng. 2009, 35, 1243-1248. [CrossRef]

44. Hong, P.; Wen, Y.; Xiong, Y.; Diao, L.; Gu, X.; Feng, H.; Yang, C.; Chen, L. Latitudinal gradients and climatic controls on reproduction and dispersal of the non-native mangrove Sonneratia apetala in China. Estuar. Coast. Shelf Sci. 2021, $248,106749$. [CrossRef]

45. Chen, L.; Wang, W.; Zhang, Y.; Lin, G. Recent progresses in mangrove conservation, restoration and research in China. J. Plant Ecol. 2009, 2, 45-54. [CrossRef]

46. Li, B.; Liao, C.; Zhang, X.; Chen, H.; Wang, Q.; Chen, Z.; Gan, X.; Wu, J.; Zhao, B.; Ma, Z.; et al. Spartina alterniflora invasions in the Yangtze River Estuary, China: An overview of current status and ecosystem effects. Ecol. Eng. 2009, 35, 511-520. [CrossRef]

47. Li, Z.; Wang, W.; Zhang, Y. Recruitment and herbivory affect spread of invasive Spartina alterniflora in China. Ecology 2014, 95, 1972-1980. [CrossRef] [PubMed]

48. Chen, H.; Liao, B.; Liu, B.; Peng, C.; Zhang, Y.; Guan, W.; Zhu, Q.; Yang, G. Eradicating invasive Spartina alterniflora with alien Sonneratia apetala and its implications for invasion controls. Ecol. Eng. 2014, 73, 367-372. [CrossRef] 
49. Liu, W.; Maung-Douglass, K.; Strong, D.R.; Pennings, S.C.; Zhang, Y. Geographical variation in vegetative growth and sexual reproduction of the invasive Spartina alterniflora in China. J. Ecol. 2016, 104, 173-181. [CrossRef]

50. Wang, W.; Wang, M. The Mangrove of China, 1st ed.; Science Press: Beijing, China, 2007. (In Chinese)

51. Iftekhar, M.S.; Saenger, P. Vegetation dynamics in the Bangladesh Sundarbans mangroves: A review of forest inventories. Wetl. Ecol. Manag. 2008, 16, 291-312. [CrossRef]

52. Zhao, S. On the prelimonary inestigation of turkestan rat, Rattus rattoides exiguus Howell, in sea beach of red-woods. Zool. Res. 1982, 3, 103. (In Chinese)

53. Smith, A.T.; Xie, Y. A Guide to the Mammals of China, 1st ed.; Princeton University Press: Princeton, NJ, USA, 2008 ; pp. $270-271$.

54. Li, Z.; Dai, J.; Ye, J.; Xu, H.; Han, S. Species, control status and outbreak causes of main pest insects in mangrove ecosystems in China. Acta Entomol. Sin. 2012, 55, 1109-1118.

55. Lin, P. The Comprehensive Report of Science Investigation on the Natural Reserve of Mangrove Wetland of Zhangjiang Estuary in Fujian, 1st ed.; Xiamen University Press: Xiamen, China, 2001. (In Chinese)

56. Zhu, X.; Meng, L.; Zhang, Y.; Weng, Q.; Morris, J. Tidal and meteorological influences on the growth of invasive Spartina alterniflora: Evidence from UAV remote sensing. Remote Sens. 2019, 11, 1208. [CrossRef]

57. Guo, X.; Pan, W.; Chen, Y.; Zhang, W.; He, T.; Liu, Y.; Liu, W.; Zhang, Y. Invasion of Spartina alterniflora and protection of mangroves in Guangdong Zhanjiang Mangrove National Nature Reserve and adjacent coastal area. For. Environ. Sci. 2018, 34, 58-63.

58. Pennings, S.C.; Richards, C.L. Effects of wrack burial in salt-stressed habitats: Batis maritima in a southwest Atlantic salt marsh. Ecography 1998, 21, 630-638. [CrossRef]

59. R Development Core Team. R: A Language and Environment for Statistical Computing, version 3.5.2; R Foundation for Statistical Computing: Vienna, Austria, 2018.

60. Farnsworth, E.J.; Ellison, A.M. Global patterns of pre-dispersal propagule predation in mangrove forests. Biotropica 1997, 29, 318-330. [CrossRef]

61. Minchinton, T.E.; Dalby-Ball, M. Frugivory by insects on mangrove propagules: Effects on the early life history of Avicennia marina. Oecologia 2001, 129, 243-252. [CrossRef] [PubMed]

62. He, Q.; Silliman, B.R. Consumer control as a common driver of coastal vegetation worldwide. Ecol. Monogr. 2016, 86, 278-294. [CrossRef]

63. Feller, I.C.; Ball, M.C.; Ellis, J.I.; Lovelock, C.E.; Reef, R.; Keith, S. Interactive effects of climate and nutrient enrichment on patterns of herbivory by different feeding guilds in mangrove forests. Glob. Ecol. Biogeogr. 2017, 26, 1326-1338. [CrossRef]

64. Boege, K.; Marquis, R.J. Facing herbivory as you grow up: The ontogeny of resistance in plants. Trends Ecol. Evol. 2005, 20, 441-448. [CrossRef]

65. Maron, J.L.; Crone, E. Herbivory: Effects on plant abundance, distribution and population growth. Proc. R. Soc. B 2006, 273, 2575-2584. [CrossRef]

66. Strauss, S.Y.; Zangrel, A.R. Plant-insect interactions in terrestrial ecosystems. In Plant-Animal Interactions. An Evolutionary Approach, 1st ed.; Herrera, C.M., Pellmyr, O., Eds.; Blackwell Science: Oxford, UK, 2002; pp. 77-106.

67. Pennings, S.C.; Bertness, M.D. Salt marsh communities. In Marine Community Ecology, 1st ed.; Bertness, M.D., Gaines, S.D., Hay, M.E., Eds.; Sinauer Associates: Sunderland, MA, USA, 2001; pp. 289-316.

68. Pfeiffer, W.J.; Wiegert, R.G. Grazers on Spartina and their predators. In The Ecology of a Salt Marsh; Pomeroy, L.R., Wiegert, R.G., Eds.; Springer: New York, NY, USA, 1981; pp. 87-112.

69. Greenberg, R.; Maldonado, J.E.; Droege, S.; McDonald, M.V. Tidal marshes: A global perspective on the evolution and conservation of their terrestrial vertebrates. BioScience 2006, 56, 675. [CrossRef]

70. Crain, C.M. Interactions between marsh plant species vary in direction and strength depending on environmental and consumer context. J. Ecol. 2008, 96, 166-173. [CrossRef]

71. Shaffer, G.P.; Day, J.W.; Hunter, R.G.; Lane, R.R.; Lundberg, C.J.; Wood, W.B.; Hillmann, E.R.; Day, J.N.; Strickland, E.; Kandalepas, D. System response, nutria herbivory, and vegetation recovery of a wetland receiving secondarily-treated effluent in coastal Louisiana. Ecol. Eng. 2015, 79, 120-131. [CrossRef]

72. Pennings, S.C.; Silliman, B.R. Linking biogeography and community ecology: Latitudinal variation in plant-herbivore interaction strength. Ecology 2005, 86, 2310-2319. [CrossRef]

73. Pennings, S.C.; Ho, C.-K.; Salgado, C.S.; Więski, K.; Davé, N.; Kunza, A.E.; Wason, E.L. Latitudinal cariation in herbivore pressure in Atlantic coast salt marshes. Ecology 2009, 90, 183-195. [CrossRef] [PubMed]

74. Zhang, H.; Liu, X.; Li, M.; Lin, Y. Tannin contents in the different parts of alien mangrove Sonneratia apetala and leaf tannin structure. J. Xiamen Univ. 2008, 47, 186-191.

75. Nasrin, S.; Hossain, M.; Alam, M.R. A Monograph on Sonneratia apetala Buch.-Ham, 1st ed.; Lap Lambert Academic Publishing: Saarbrucken, Germany, 2017; pp. 5-15.

76. Krauss, K.W.; Lovelock, C.E.; McKee, K.L.; López-Hoffman, L.; Ewe, S.M.L.; Sousa, W.P. Environmental drivers in mangrove establishment and early development: A review. Aquat. Bot. 2008, 89, 105-127. [CrossRef]

77. Guo, H.; Zhang, Y.; Lan, Z.; Pennings, S.C. Biotic interactions mediate the expansion of black mangrove (Avicennia germinans) into salt marshes under climate change. Glob. Chang. Biol. 2013, 19, 2765-2774. [CrossRef] 
78. McKee, K.L.; Rooth, J.E. Where temperate meets tropical: Multi-factorial effects of elevated $\mathrm{CO}_{2}$, nitrogen enrichment, and competition on a mangrove-salt marsh community: Multi-factorial controls on vegetation shifts. Glob. Chang. Biol. 2008, 14, 971-984. [CrossRef]

79. Chen, E.; Blaze, J.A.; Smith, R.S.; Peng, S.; Byers, J.E. Freeze tolerance of poleward-spreading mangrove species weakened by soil properties of resident salt marsh competitor. J. Ecol. 2020, 108, 1725-1737. [CrossRef]

80. Gurevitch, J.; Morrison, J.A.; Hedges, L.V. The interaction between competition and predation: A meta-analysis of field experiments. Am. Nat. 2000, 155, 435-453. [CrossRef] 